\title{
Follicular blood flow, antrum growth and angiogenic mediators in mares from ovulation to deviation
}

\author{
Amal Mhmoud Abo El-Maaty ${ }^{1,3}$, EIShymaa Ahmad Abdelnaby ${ }^{2}$ \\ ${ }^{1}$ Animal Reproduction and AI Dept., Veterinary Division, National Research Center, Dokki, Egypt. \\ ${ }^{2}$ Theriogenology Department, Faculty of Veterinary Medicine, Cairo University, Giza, Egypt.
}

\begin{abstract}
This study assumed that vascular perfusion, antrum growth, leptin, nitric oxide (NO) and insulin like growth factor 1 (IGF-1) play an important role during selection and deviation of mares' next dominant follicle. Five broad mares were subjected to daily rectal Doppler ultrasonographic examination and blood sampling for 2 successive estrous cycles $(\mathrm{n}=10)$. Using electronic calipers, three diameters were taken to estimate area and volume of first (F1O) and second large follicles (F2O) on the ovulated ovary with first (F1C) and second large follicles (F2C) on contralateral ovary. Follicles' area, circumference, antrum area, area of color- and power- Doppler were measured in pixels. Days after ovulation affected significantly $(\mathrm{P}<0.0001)$ follicles blood flow, dimensions and measured hormones. On day 4 after ovulation, the follicle that had a mean diameter of $1.31 \pm 0.06$ and reached to $1.41 \pm$ $0.06 \mathrm{~cm}$ on day 5 , the lowest area $/ \mathrm{cm}^{2}(1.38 \pm 0.18)$, highest area/pixsel $(10229 \pm 366)$, antrum/pixel $(7671$ $\pm 357)$, highest volume $(5.54 \pm 0.09)$, lowest power blood flow area $(2060.25 \pm 8.52)$ and percent colored pixels of follicle without antrum $(80.57 \pm 0.72)$ was selected. Deviation started from day 9 and completed on day 10 where the dominant follicle attained the highest diameter, area, volume, area and antrum area in pixels, color blood flow red area, and percent of colored pixels of follicle without its antrum, leptin, IGF-1 and NO but the lowest power blood flow area and percent of total follicle colored pixels. Our assumption that follicle selection and deviation did not depend only on diameter but also on blood flow, antrum growth, leptin and IGF-1 was proved.
\end{abstract}

Keywords: blood flow, deviation, follicle selection, mare, reproductive hormones.

\section{Introduction}

Follicle selection and deviation in mares (Gastal et al., 1997, 1999b, 2006; Donadeu and Ginther, 2004), and cattle (Ginther et al., 1996; Fortune et al., 2001), depended on comparing diameter of recruited follicles but other morphological dimensions of the follicle such as follicle area, volume and follicle antrum growth had not received much interest in such species. Follicular antrum growth was studied in primate (Wulff et al., 2002) and recently several hypotheses were tested for explaining the development of follicular fluid within the antrum (Rodgers and Irving-Rodgers, 2010).
Follicular fluid derives mainly from plasma via the vascular component in the follicle wall (Fahiminiya and Gérard, 2010). The membrana granulosa receive their nutrients by diffusion from the vascularized theca and the antrum plays a role for determining the volume of the granulosa layer (Bächler et al., 2014).

During follicle development, a broad vascular plexus creates in the theca layer surrounding the avascular basement membrane and granulosa layer (Okuda et al., 1982; Feranil et al., 2004). This vascular framework in individual follicles assumes a part of determination and development of the dominant follicle (Kitawaki et al., 1999). During follicle growth, the extensive vascular plexus not only deliver gonadotropins and nutrients but also plays a role in the selection and growth of the dominant follicle (Wulff et al., 2002). The vascular framework increased after induction of ovulation in equine (Kerban et al., 1999). Doppler ultrasound had been used in cattle to study follicular blood flow of the first follicular wave and follicle deviation (Acosta et al., 2005; Pancarc et al., 2011; Miura et al., 2014), and in mare to compare the future dominant and subordinate follicle blood flow (Gastal et al., 1999a; Acosta et al., 2004a, b). In mares, dominant next ovulatory follicle starts deviation from $2.2 \mathrm{~cm}$ till reach $\geq 3.0 \mathrm{~cm}$ in diameter but the follicle that reached diameter of $2.2 \mathrm{~cm}$ but transiently stopped growth then resumed growth but its diameter is always few $\mathrm{mm}$ lower than the dominant one $(<3.0 \mathrm{~cm})$ is considered next subordinate (Gastal et al., 1997, 1999b; Ginther et al., 2004a, 2007, 2009).

Leptin as adipocytes hormone is implicated in ovarian function and enhances ovulation (Roman et al., 2005). It is also considered an angiogenic factor (SierraHonigmann et al., 1998). Follicular fluid concentration of leptin was shown to reflect serum leptin (Agarwal et al., 1999), with marked correlation between them during luteal phase (Dayi et al., 2005). Granulosa cells have also the ability to synthesize leptin (Zachow and Magoffin, 1997). Follicular fluid leptin had also been implicated to atresia in small follicles (Dayi et al., 2005). In mares, intrafollicular leptin concentration inversely related to the percentage of the follicle wall with blood-flow signal (Gastal et al., 2010).

IGF system had been identified in the mare follicular fluid and blood (Spicer et al., 1991), and has a role in follicle selection and deviation (Donadeu and Ginther, 2002; Ginther et al., 2004b, c, d). Messenger RNA for IGF-I were localized to granulosa cells of small antral, subordinate, and dominant follicles (Yuan et al., 1998) and IGF system was reported to have a 
critical intrafollicular role in the differential changes in concentrations of follicular-fluid factors between the future dominant and subordinate follicles, leading to the development of follicle selection (Ginther et al., 2004a) and deviation in mares (Ginther, 2012).

The endothelial nitric oxide synthetase (eNOS) derived NO is the most important vasodilator and maintains a constant vasorelaxation, normal blood pressure and adequate tissue perfusion (Wood et al, 2013). NO is one of such substances that plays a crucial role in folliculogenesis, regulating angiogenesis and steroid production (El-Sherry et al., 2013). During follicular development, eNOS was expressed in theca cells and in mural granulosa cells and the increase of NO was correlated with the increase of estrogen (Rosselli et al., 1994). Folliculogenesis involves the participation of both growth and programmed cell death, and NO regulates both of these processes (Rosselli et al., 1998), so we assume a role of circulating leptin, NO and IGF-1 during follicle selection and deviation in mares.

In our locality, mares cycle all the year (Abo El-Maaty et al., 2015), but breeding and foaling commences during winter (Abo El-Maaty and Gabr, 2010), so our aims were to track growth and blood flow of the two large follicles on both ovaries from the day after ovulation till one of them would achieve $\geq 30 \mathrm{~mm}$ in diameter to prove that follicle selection depends on its blood flow, dimensions, antrum expansion, leptin, NO, IGF-1 and estradiol.

\section{Materials and Methods}

\section{Animals}

Five non lactating brood mares (3-12 years old) of European X Egyptian crossbred horses of moderate body condition were subjected to Doppler ultrasonographic examination throughout two estrous cycles $(n=10)$ for the first 12 days after ovulation. Mares were given one week off rectal examinations between the two estrous cycles. Mares were granted from the Training Department (El-Basaten Horsley, Ministry of interior) and kept in an indoor paddock with partition individually with a stallion at the end of the same stable to confirm estrus signs. Mares were kept under natural day light and temperature and artificial lightening was used at night within the paddock. Mares were maintained on a commercial pelleted ration and hay with free access to water. This study was conducted at the Department of Theriogenology, Faculty of Veterinary Medicine, Cairo University $\left(30.0276^{\circ} \mathrm{N}\right.$, $31.2101^{\circ} \mathrm{E}$ ) from June 15 to July 28,2014 . The Experiment was conducted in accordance with Institutional Animal Care and Use Committee (IACUC) of faculty of Science, Cairo University.

Before directing this work, mares were examined 3 times at weekly interval by ultrasound to affirm ovarian cyclicity and ovulation. Estrous regularity depended on the presence of a stallion within the same paddok with mares. No pharmacological drugs were used to synchronize estrus. Ovulation was determined by the disappearance of a large dominant follicle $(>30 \mathrm{~mm})$ and the development of a corpus luteum in its location and accompanied by serum progesterone levels $>3 \mathrm{ng} / \mathrm{ml}$. The last day the dominant follicle monitored was considered the day of ovulation (day 0) and days after ovulation (day 1 to day 12) represented luteal phase.

\section{Doppler ltrasound examination}

A pulsed-wave Doppler ultrasound scanner equipped with $12 \mathrm{MHz}$ linear-array transrectal transducer (SonovetR3, Medison, Samsung, South Korea) was used for the examination of ovaries and uterus. All scans were performed by the same operator along the study. All exams were performed from 8 to 11 a.m. to avoid the summer high temperature and humidity. The same color- and power- flow mode of Doppler setting were used to quantify the blood flow vascularization area within the follicle wall. Identical color gain settings were used for all scans.

\section{Follicles}

After ovulation, the two largest follicles of diameter $\geq 10 \mathrm{~mm}$ on both ovaries were tracked for deciding the next ovulatory one during development of corpus luteum. For each day, three intersecting diameters of the two large follicles per ovary were measured with the electronic calipers of the ultrasound and the maximum diameter was included in the analysis. The two large diameters were multiplied to measure the area $/ \mathrm{cm}^{2}$ using the equation $\left(3.14 \mathrm{xD}_{1} / 2 \mathrm{xD}_{2} / 2\right)$ and the three diameters were used to measure the volume using the mathematical equation $\left(4 / 3 \times 3.14 \times \mathrm{D}_{1} / 2 \times \mathrm{D}_{2} / 2 \times \mathrm{D}_{3} / 2\right)$. Follicles were classified into first large follicle on the previously ovulated ovary and carrying the corpus luteum (F1O) and the second large follicle on the ovulatory ovary (F2O). On the contralateral ovary, the first (F1C) and second large $(\mathrm{F} 2 \mathrm{C})$ were also tracked.

Real-time B mode/color Doppler images were stored in the hard drive of the scanner then images were exported at the end of the experiment using a removable hard disk to a computer for blood flow area analyses in the laboratory. The blood flow areas in the follicle wall were measured by outlining a belt circumscribing the anechoic antral cavity of follicle as described in cows (Acosta et al., 2003) and mares (Bollwein et al., 2002). The color blood flow red and blue areas and area of single color power Doppler images were counted per pixel using Adobe PhotoShop CC software (1990-2013, Adobe Systems). A magnetic Lasso tool was used to outline the color- and power area and then a measurement was used to count the selected areas in pixels. Follicles were also outlined then their areas and circumference (perimeter) were measured in pixels. Follicle area and antrum area was also measured in pixels using the same program. The percent of the colored area in pixels of the total follicle area was measured using the equation: (area of color power Doppler in pixel/area of the follicle in pixel x100). The percent of colored area of the follicle without its antrum was counted using the equation: [area of the color power Doppler in pixel/ (area of follicle in 
pixel- area of antrum in pixel)x100]. As well as, area of power blood flow -area of red color blood flow was also calculated for all tracked follicles to estimate the actual vascularization within them.

\section{Blood sampling and hormone assaying}

Daily blood samples were obtained from the jugular vein shortly after ultrasound examination using vacutainer tubes with anticoagulant, then centrifuged at $2000 \mathrm{x} g$ for $10 \mathrm{~min}$. Plasma was harvested and stored at $-18^{\circ} \mathrm{C}$ until hormone assaying. Leptin was assayed using Leptin ELISA (Sandwich) previously used for horses in our Laboratory (Abo El-Maaty and Gabr, 2010) using commercial solid phase ELISA kit of DRG diagnostics (EIA-2395, DRG International, Inc., USA) based on the sandwich principle. Sensitivity of the assay was 1.0 $\mathrm{ng} / \mathrm{ml}$. Intra- and inter-assay coefficients of variation were 3.1 and 9.7\%. Estradiol (E2) is a commercial solid phase ELISA (EIA-2693, DRG, International, Inc., USA). The range of the assay was between $9.7 \mathrm{pg} / \mathrm{ml}$ $2000 \mathrm{pg} / \mathrm{ml}$, with cross reactivity with Estriol (0.05\%) and Estrone $(0.2 \%)$. The analytical sensitivity was found to be $9.71 \mathrm{pg} / \mathrm{ml}$. Intra- and inter-assay coefficients of variation of estradiol were 2.71 and $6.72 \%$. Insulin like growth factor-I (IGF-1 600) is a commercial solid phase ELISA (EIA-4140, DRG, International, Inc., USA). Range of the assay is between $1.29-600 \mathrm{ng} / \mathrm{ml}$. The analytical sensitivity was found to be $1.29 \mathrm{ng} / \mathrm{ml}$. Intra- and inter-assay coefficients of variation were 6.62 and $7.79 \%$.

For measuring nitric oxide metabolites (NOMs), $100 \mu \mathrm{l}$ of plasma samples were mixed with an equal volume of freshly prepared Greiss reagent and incubated for $10 \mathrm{~min}$ at room temperature and absorbance was measured at $540 \mathrm{~nm}$ using a Microtiter plate reader (Abo El-Maaty and El-Shahat, 2012). Concentrations of circulating hormones were normalized to each tracked follicle growth by referring the daily change in hormones to each follicle change in growth during days after ovulation (day 0 to day 12 ).

\section{Statistical analysis}

Data are presented as Mean \pm SEM (Standard error of mean) using SPSS software, 2007. Simple one way ANOVA was used to study effect of class of follicle and days after ovulation on each follicle diameter $/ \mathrm{cm}$, area $/ \mathrm{cm}^{2}$, volume $/ \mathrm{cm}^{3}$, area in pixels, perimeter in pixels (circumference), antrum area circulatory $\%$, area of color- and power- blood flow and colored pixels \%. Duncan's Multiple Range Test was used to differentiate between significant means. Data are presented in Plots with error bars. Multivariate General Linear Model was used to study the effect of days after ovulation and follicle class using the model (12 days x 4 follicle class) and animal as a co-variate on the studied parameters.

\section{Results}

Class of follicle had significant affected on diameter $(\mathrm{P}=0.0001), \quad$ area $/ \mathrm{cm}^{2}(\mathrm{P}=0.0001)$, volume $/ \mathrm{cm}^{3}(\mathrm{P}=0.0001)$, area in pixels $(\mathrm{P}=0.0001)$, antrum area $(\mathrm{P}=0.0001)$, circumference $(\mathrm{P}=0.0001)$, circulatory \% $(\mathrm{P}=0.0001)$, color blood flow blue $(\mathrm{P}=0.002)$, color blood flow red area $(\mathrm{P}=0.0001)$, power blood flow area $(\mathrm{P}=0.0001)$, colored pixels $\%$ $(\mathrm{P}=0.001)$, estradiol $(\mathrm{P}=0.0001)$, and progesterone (P4) concentrations $(\mathrm{P}=0.001)$ of the 2 large follicles on the dominant ovary (carrying the CL) and the two follicles on the non-dominant ovary (Table 1).

Days after ovulation significantly affected diameter $(\mathrm{P}=0.0001), \quad$ area $/ \mathrm{cm}^{2}(\mathrm{P}=0.0001)$, volume $/ \mathrm{cm}^{3}(\mathrm{P}=0.0001)$, area in pixels $(\mathrm{P}=0.0001)$, antrum area $(\mathrm{P}=0.0001)$, circumference $(\mathrm{P}=0.0001)$, circulatory \% $(\mathrm{P}=0.0001)$, color blood flow blue area $(\mathrm{P}=0.0001)$, color blood flow red area $(\mathrm{P}=0.0001)$, power blood flow area $(\mathrm{P}=0.0001)$, colored pixels $\%$ $(\mathrm{P}=0.0001)$, estradiol $(\mathrm{P}=0.0001)$, progesterone $(\mathrm{P}=0.0001)$ of the first $(\mathrm{F} 1 \mathrm{O})$ and second $(\mathrm{F} 2 \mathrm{O})$ large follicles on the dominant ovary. Also, days after ovulation affected IGF-1 ( $\mathrm{P}=0.004 ; \mathrm{P}=0.007)$ and leptin $(\mathrm{P}=0.0001 ; \mathrm{P}=0.003)$ of F1Oand $\mathrm{F} 2 \mathrm{O}$, respectively. On the contralateral ovary, days after ovulation affected significantly diameter $(\mathrm{P}=0.0001)$, area $/ \mathrm{cm}^{2}(\mathrm{P}=0.0001)$, volume $/ \mathrm{cm}^{3}(\mathrm{P}=0.0001)$, area in pixels $(\mathrm{P}=0.0001)$, antrum area $(\mathrm{P}=0.0001)$, circumference $(\mathrm{P}=0.0001)$, circulatory \% $(\mathrm{P}=0.001)$, color blood flow blue $(\mathrm{P}=0.0001)$, color blood flow red area $(\mathrm{P}=0.0001)$, power blood flow area $(\mathrm{P}=0.0001)$, colored pixels \% $(\mathrm{P}=0.0005)$, estradiol $(\mathrm{P}=0.0001)$, progesterone $(\mathrm{P}=0.0001), \mathrm{IGF}-1(\mathrm{P}=0.004 ; \mathrm{P}=0.007)$ and leptin $(\mathrm{P}=0.0001)$ of the first large follicle $(\mathrm{F} 1 \mathrm{C})$. Similarly, days after ovulation significantly affected the diameter $(\mathrm{P}=0.0001)$, area $/ \mathrm{cm}^{2}(\mathrm{P}=0.0001)$, volume $/ \mathrm{cm}^{3}(\mathrm{P}=0.0001)$, area in pixels $(\mathrm{P}=0.0001)$, antrum area $(\mathrm{P}=0.0001)$, circumference $(\mathrm{P}=0.0001)$, color blood flow blue $(\mathrm{P}=0.0001)$, color blood flow red area $(\mathrm{P}=0.0001)$, power blood flow area $(\mathrm{P}=0.0001)$, area of colored pixels \% $(\mathrm{P}=0.0001)$, area of colored pixels without antrum \% $(\mathrm{P}=0.006)$, estradiol $(\mathrm{P}=0.0001)$, progesterone $(\mathrm{P}=0.0001), \mathrm{IGF}-1(\mathrm{P}=0.004)$ and leptin $(\mathrm{P}=0.0001)$ of the second large follicle (F2C; Table 1). Effect of days after ovulation, class of follicle, days $\mathrm{x}$ class of follicle and animal is presented in Table 2 .

Selection of the next dominant follicle started from day 4 and completed on day 5 where its diameter increased from $1.31 \pm 0.06$ and reached to $1.41 \pm 0.06 \mathrm{~cm}$ on day 5 , area $/ \mathrm{cm}^{2}$ increased from $1.38 \pm 0.18$ to $1.50 \pm 0.30$, volume increased from $5.54 \pm 0.09$ to $6.00 \pm 0.03$, area/pixsel increased from $10229 \pm 366$ to $15188 \pm 217$, antrum/pixel increased from $7671 \pm 357$ to $12630 \pm 206$, color blood flow blue area increased slightly from $1435 \pm 10$ to $1461 \pm 33$, but its color blood flow red area decreased from $1403 \pm 19$ to $1294 \pm 7.0$, power blood flow area decreased from $2060.25 \pm 8.52$ to $1950 \pm 124$, colored pixels percent decreased from $20.33 \pm 0.74$ to $12.91 \pm$ 0.95 and colored pixels of follicle without antrum decreased from $80.57 \pm 0.72$ to $76.24 \pm 4.88$ on day 5 .

Selection of the next subordinate follicle also started from day 4 and completed on day 5 where its 
diameter increased from $1.66 \pm 0.19$ and reached to $1.81 \pm 0.19 \mathrm{~cm}$ on day 5 , area $/ \mathrm{cm}^{2}$ increased from $2.86 \pm 0.55$ to $3.25 \pm 0.61$, volume increased from $2.78 \pm 0.68$ to $3.28 \pm 0.77$, area/pixsel increased from $8252.25 \pm 164.9$ to $13085 \pm 30.65$, antrum $/$ pixel increased from $5644.2 \pm 1656$ to $10477 \pm 45.9$, color blood flow blue area increased from $1235.75 \pm 8.8$ to $1284 \pm 12$, power blood flow area increased from $2138 \pm 43.6$ to $2400 \pm 22.9$, and colored pixels of follicle without antrum increased from $78.67 \pm 2.82$ to $83.83 \pm 4.87$ but its color blood flow red area decreased from $1599.25 \pm 19.4$ to $1537.75 \pm 6.4$, and colored pixels percent decreased from $70.18 \pm 3.18$ to $18.34 \pm 0.15$ on day 5 .

Both next dominant and next subordinate follicles continued growing till day 8 where their diameter significantly $(\mathrm{P}<0.0001)$ increased in parallel, and they attained a diameter exceeding $2 \mathrm{~cm}$ then deviation to dominance started from day 9 where the next dominant growth rate is higher than the next subordinate one (Fig. 1A). By day 11, the next dominant follicle diameter exceeded $3.0 \mathrm{~cm}$ but the next subordinate diameter was lower than $2.6 \mathrm{~cm}$.

During deviation of the next dominant follicle its diameter increased on day 9 from $2.25 \pm 0.07$ and reached to $3.06 \pm 0.26 \mathrm{~cm}$ on day 11 , area $/ \mathrm{cm}^{2}$ increased from $3.83 \pm 0.59$ to $6.28 \pm 1.36$, volume increased from $7.62 \pm 0.03$ to $10.34 \pm 0.29$, area/pixsel increased from $21023 \pm 317$ to $26295 \pm 444$, antrum area /pixel increased from $18465 \pm 306$ to $23728 \pm 424$, color blood flow blue area increased from $1879.25 \pm 11$ to $2154 \pm 19$, power blood flow area increased from $2637.25 \pm 127$ to $2833 \pm 131$ but its color blood flow red area decreased from $1032 \pm 9$ to $916 \pm 67$ colored pixels percent decreased from $12.59 \pm 0.69$ to $10.83 \pm 0.67$ and colored pixels of follicle without antrum transiently increased from $89.74 \pm 7.41$ on day 9 to $93.99 \pm 13.26$ on day 10 then decreased sharply to $85.76 \pm 12.60$ on 11 and continued decreasing till reach $73.86 \pm 5.02$ on 12 after ovulation. Deviation of the next dominant follicle started from day 9 and was affirmed by a continuous increase of its antrum area.

Table 1. Mean daily change of different follicle dimensions during preovulatory period.

\begin{tabular}{|c|c|c|c|c|c|}
\hline parameter & F1O & $\mathrm{F} 2 \mathrm{O}$ & F1C & $\mathrm{F} 2 \mathrm{C}$ & D \\
\hline $\mathrm{N}$ & 112 & 113 & 116 & 114 & P-value \\
\hline Diameter/cm & $\begin{array}{l}1.98 \\
\pm 0.06^{b^{*}}\end{array}$ & $\begin{array}{l}2.02 \\
\pm 0.04^{b^{*}}\end{array}$ & $\begin{array}{l}2.05 \\
\pm 0.04^{b^{*}}\end{array}$ & $\begin{array}{l}1.64 \\
\pm 0.05^{a^{*}}\end{array}$ & 0.0001 \\
\hline Area $/ \mathrm{cm}^{2}$ & $\begin{array}{l}3.15 \\
\pm 0.19^{\mathrm{a}^{*}}\end{array}$ & $\begin{array}{l}4.08 \\
\pm 0.21^{b^{*}}\end{array}$ & $\begin{array}{l}3.83 \\
\pm 0.15^{b^{*}}\end{array}$ & $\begin{array}{l}2.90 \\
\pm 0.15^{\mathrm{a}^{*}}\end{array}$ & 0.0001 \\
\hline Volume $/ \mathrm{cm}^{3}$ & $\begin{array}{l}6.96 \\
\pm 0.17^{\mathrm{c}^{*}}\end{array}$ & $\begin{array}{l}4.53 \\
\pm 0.37^{\mathrm{a}^{*}}\end{array}$ & $\begin{array}{l}3.913 \\
\pm 0.25^{b^{*}}\end{array}$ & $\begin{array}{l}2.78 \\
\pm 0.20^{\mathrm{a}^{*}}\end{array}$ & 0.0001 \\
\hline Area/pixel & $\begin{array}{l}16539.54 \\
\pm 755.84^{b^{*}}\end{array}$ & $\begin{array}{l}14043.72 \\
\pm 527.93^{\mathrm{a}^{*}}\end{array}$ & $\begin{array}{l}13863.48 \\
\pm 436.79^{a^{*}}\end{array}$ & $\begin{array}{l}15441.90 \\
\pm 327.36^{b^{*}}\end{array}$ & 0.0001 \\
\hline Antrum area/pixel & $\begin{array}{l}13979.54 \\
\pm 528.84^{\mathrm{c}^{*}}\end{array}$ & $\begin{array}{l}11494.72 \\
\pm 527.93^{\mathrm{ab}^{*}}\end{array}$ & $\begin{array}{l}11253.48 \\
\pm 346.79^{\mathrm{a}^{*}}\end{array}$ & $\begin{array}{l}12548.66 \\
\pm 319.61^{\mathrm{b}^{*}}\end{array}$ & 0.0001 \\
\hline Circumference & $\begin{array}{l}420.13 \\
\pm 10.73^{\mathrm{a}^{*}}\end{array}$ & $\begin{array}{l}465.69 \\
\pm 16.94^{b^{*}}\end{array}$ & $\begin{array}{l}395.59 \\
\pm 13.24^{\mathrm{a}^{*}}\end{array}$ & $\begin{array}{l}488.32 \\
\pm 16.40^{b^{*}}\end{array}$ & 0.0001 \\
\hline Circulatory $\%$ & $\begin{array}{l}75.16 \\
\pm 0.55^{\mathrm{c}^{*}}\end{array}$ & $\begin{array}{l}72.92 \\
\pm 0.62^{b^{*}}\end{array}$ & $\begin{array}{l}70.46 \\
\pm 0.41^{a^{\text {a†ं* }}}\end{array}$ & $\begin{array}{l}69.98 \\
\pm 0.48^{\mathrm{a}^{\dagger *}}\end{array}$ & 0.0001 \\
\hline Color blood flow blue area & $\begin{array}{l}1679.31 \\
\pm 38.75^{\mathrm{ab}^{*}}\end{array}$ & $\begin{array}{l}1750.95 \\
\pm 37.96^{\mathrm{bc}^{*}}\end{array}$ & $\begin{array}{l}1598.62 \\
\pm 31.14^{\mathrm{ab} *}\end{array}$ & $\begin{array}{l}1862.23 \\
\pm 91.22^{\mathrm{c}^{*}}\end{array}$ & 0.002 \\
\hline Color blood flow red area & $\begin{array}{l}1230.04 \\
\pm 32.24^{\mathrm{c}^{*}}\end{array}$ & $\begin{array}{l}982.58 \\
\pm 27.79^{\mathrm{a}^{*}}\end{array}$ & $\begin{array}{l}1135.48 \\
\pm 27.29^{b^{*}}\end{array}$ & $\begin{array}{l}1268.36 \\
\pm 33.97^{\mathrm{c}^{*}}\end{array}$ & 0.0001 \\
\hline Power blood flow area & $\begin{array}{l}2452.77 \\
\pm 55.21^{\mathrm{a}^{*}}\end{array}$ & $\begin{array}{l}2702.50 \\
\pm 42.27^{b^{*}}\end{array}$ & $\begin{array}{l}2708.66 \\
\pm 62.52^{b^{*}}\end{array}$ & $\begin{array}{l}2732.66 \\
\pm 22.40^{b^{*}}\end{array}$ & 0.0001 \\
\hline Colored pixels $\%$ & $\begin{array}{l}17.41 \\
\pm 0.84^{\mathrm{a}^{*}}\end{array}$ & $\begin{array}{l}20.98 \\
\pm 0.34^{\mathrm{bc}^{*}}\end{array}$ & $\begin{array}{l}22.84 \\
\pm 2.81^{\mathrm{b} \dagger \dagger}\end{array}$ & $\begin{array}{l}18.78 \\
\pm 0.43^{\mathrm{ab}^{*}}\end{array}$ & 0.001 \\
\hline Colored pixels $\%$ without antrum & $\begin{array}{l}83.09 \\
\pm 1.85\end{array}$ & $\begin{array}{l}80.22 \\
\pm 2.11\end{array}$ & $\begin{array}{l}81.60 \\
\pm 2.33\end{array}$ & $\begin{array}{l}81.76 \\
\pm 1.81^{\dagger \dagger}\end{array}$ & 0.14 \\
\hline $\mathrm{E} 2 \mathrm{Pg} / \mathrm{mL}$ & $\begin{array}{l}187.72 \\
\pm 5.94^{\mathrm{b}^{*}}\end{array}$ & $\begin{array}{l}157.52 \\
\pm 7.25^{\mathrm{a}^{*}}\end{array}$ & $\begin{array}{l}186.30 \\
\pm 6.46^{b^{*}}\end{array}$ & $\begin{array}{l}177.74 \\
\pm 5.58^{b^{*}}\end{array}$ & 0.0001 \\
\hline $\mathrm{P} 4 \mathrm{ng} / \mathrm{mL}$ & $\begin{array}{l}15.23 \\
\pm 0.39^{*}\end{array}$ & $\begin{array}{l}15.24 \\
\pm 0.40^{*}\end{array}$ & $\begin{array}{l}14.89 \\
\pm 0.29^{*}\end{array}$ & $\begin{array}{l}14.68 \\
\pm 0.29^{*}\end{array}$ & 0.001 \\
\hline $\mathrm{IGF}-1 \mathrm{ng} / \mathrm{mL}$ & $\begin{array}{l}297.06 \\
\pm 10.21^{\dagger \dagger}\end{array}$ & $\begin{array}{l}288.00 \\
\pm 11.26^{\dagger \dagger}\end{array}$ & $\begin{array}{l}293.30 \\
\pm 8.15\end{array}$ & $\begin{array}{l}289.15 \\
\pm 8.12^{\dagger \dagger}\end{array}$ & 0.90 \\
\hline Leptin ng/mL & $\begin{array}{l}12.42 .53 \\
\pm 0.66^{*}\end{array}$ & $\begin{array}{l}12.87 \\
\pm 0.83^{\dagger \dagger}\end{array}$ & $\begin{array}{l}12.44 \\
\pm 0.68^{*}\end{array}$ & $\begin{array}{l}12.41 \\
\pm 0.72^{*}\end{array}$ & 0.97 \\
\hline $\mathrm{NO} \mu \mathrm{mol} / \mathrm{L}$ & $\begin{array}{l}33.43 \\
\pm 1.39^{\dagger}\end{array}$ & $\begin{array}{l}34.27 \\
\pm 1.93^{\dagger *}\end{array}$ & $\begin{array}{l}32.71 \\
\pm 1.32^{\dagger}\end{array}$ & $\begin{array}{l}33.04 \\
\pm 1.39^{\dagger *}\end{array}$ & 0.91 \\
\hline
\end{tabular}

Means with different superscripts $(\mathrm{a}, \mathrm{b}, \mathrm{c})$ within row are significant at $\mathrm{P}<0.05$. Within each cell the effect of days after ovulation is represented by $\left(^{*}\right)$ means significant at $\mathrm{P}<0.0001,(\dagger)$ significant at $\mathrm{P}<0.05(=0.04),\left({ }^{\dagger}\right)$ significant at $\mathrm{P}<0.01(\mathrm{P}=0.004),\left(\dagger^{\dagger *}\right)$ significant at $\mathrm{P}=0.001,\left({ }^{\dagger *}\right)$ significant at $\mathrm{P}>0.05(\mathrm{P}=0.07)$. 
Table 2. Effect of days after ovulation, class of follicle, day* class and animal on follicles dimension, blood flow parameters and circulating hormones.

\begin{tabular}{|c|c|c|c|c|c|c|c|}
\hline Parameter & $\begin{array}{l}\text { Corrected } \\
\text { Model }\end{array}$ & Intercept & $\begin{array}{l}\text { Days after } \\
\text { ovulation }\end{array}$ & $\begin{array}{l}\text { Class of } \\
\text { follicle }\end{array}$ & Day*class & Animal & $\mathrm{R}^{2}$ \\
\hline Diameter/cm & 0.0001 & 0.0001 & 0.0001 & 0.052 & 0.005 & 0.82 & 0.46 \\
\hline Area $/ \mathrm{cm}^{2}$ & 0.0001 & 0.0001 & 0.0001 & 0.041 & 0.41 & 0.87 & 0.39 \\
\hline Volume $/ \mathrm{cm}^{3}$ & 0.0001 & 0.0001 & 0.0001 & 0.0001 & 0.22 & 0.05 & 0.53 \\
\hline Area/pixel & 0.0001 & 0.0001 & 0.0001 & 0.0001 & 0.0001 & 0.06 & 0.80 \\
\hline Antrum area/pixel & 0.0001 & 0.0001 & 0.0001 & 0.0001 & 0.0001 & 0.03 & 0.78 \\
\hline Circumference & 0.0001 & 0.0001 & 0.0001 & 0.0001 & 0.0001 & 0.25 & 0.49 \\
\hline Circulatory \% & 0.0001 & 0.0001 & 0.65 & 0.0001 & 0.011 & 0.28 & 0.29 \\
\hline $\begin{array}{l}\text { Color blood flow } \\
\text { away probe(blue) }\end{array}$ & 0.0001 & 0.0001 & 0.0001 & 0.0001 & 0.28 & 0.0001 & 0.51 \\
\hline $\begin{array}{l}\text { Color blood flow } \\
\text { toward probe (red) }\end{array}$ & 0.0001 & 0.0001 & 0.0001 & 0.0001 & 0.0001 & 0.22 & 0.69 \\
\hline $\begin{array}{l}\text { Power blood flow } \\
\text { area }\end{array}$ & 0.0001 & 0.0001 & 0.0001 & 0.0001 & 0.008 & 0.21 & 0.65 \\
\hline Colored pixels \% & 0.02 & 0.0001 & 0.02 & 0.13 & 0.35 & 0.22 & 0.15 \\
\hline $\begin{array}{l}\text { Colored pixels } \% \\
\text { without antrum }\end{array}$ & 0.13 & 0.0001 & 0.72 & 0.009 & 0.008 & 0.45 & 0.12 \\
\hline E2 Pg/mL & 0.0001 & 0.0001 & 0.0001 & 0.0001 & 0.0001 & 0.001 & 0.95 \\
\hline $\mathrm{P} 4 \mathrm{ng} / \mathrm{mL}$ & 0.0001 & 0.0001 & 0.0001 & 0.10 & 0.056 & 0.98 & 0.79 \\
\hline IGF-1ng/mL & 0.0001 & 0.0001 & 0.0001 & 0.71 & 1.000 & 0.16 & 0.44 \\
\hline Leptin ng/mL & 0.0001 & 0.0001 & 0.0001 & 0.98 & 1.000 & 0.0001 & 0.64 \\
\hline $\mathrm{NO} \mu \mathrm{mol} / \mathrm{L}$ & 0.0001 & 0.0001 & 0.0001 & 0.97 & 1.000 & 0.0001 & 0.39 \\
\hline
\end{tabular}

During deviation of the next subordinate follicle its diameter slowly increased on day 9 from $2.24 \pm 0.18$ and reached to $2.56 \pm 0.11 \mathrm{~cm}$ on day 11 , area $/ \mathrm{cm}^{2}$ increased from $5.12 \pm 0.78$ to $5.58 \pm 0.49$, volume increased from $6.11 \pm 1.24$ to $7.31 \pm 0.96$, area/pixsel increased from $16024 \pm 140$ to $20083.2 \pm 179$, antrum/pixel increased from $13416 \pm 151.2$ to 17470 \pm 190.2 , color blood flow blue area increased from $1533 \pm 2.95$ to $2076 \pm 21.32$, power blood flow area increased from $2826 \pm 12.7$ to $3805 \pm 12.41$ but its color blood flow red area decreased from $960.75 \pm 3.45$ to $844 \pm 5.15$. The colored pixels percent of the next subordinate follicle slightly decreased from $17.64 \pm 0.09$ transiently on day 10 to $17.16 \pm 0.18$, then re-increased on day 11 to reach $18.96 \pm 0.11$ but colored pixels of follicle without antrum transiently increased from $86.31 \pm 6.29$ on day 9 to reach $98.01 \pm 8.22$ on day 10 , then decreased sharply to $80.48 \pm 12.42$ on 11 after ovulation. On day 9 , area of the next subordinate follicle transiently decreased due to the decrease of its antrum area (Fig. 1D), that continued to increase from day 10 in a rate slower than the next dominant one.

Although area of next dominant follicle increased $(\mathrm{P}<0.0001)$ in a rate lower than the next subordinate after its selection but from day 10 the next dominant attained a higher area compared to the next subordinate (Fig. 1B).

Both follicle area (Fig. 1C), and antrum area (Fig. 1D) measured in pixels of the both next dominant and subordinate follicles started to increase significantly $(\mathrm{P}<0.0001)$ from day 4 but the rate of increase of the next dominant is higher than that of the next subordinate (Fig. 1C).

During the increase $(\mathrm{P}<0.0001)$ of $\mathrm{F} 2 \mathrm{C}$ circumference from day 1 till day 12 in a higher rate than that of next dominant $(\mathrm{P}<0.0001)$ and subordinate $(\mathrm{P}<0.0001)$ follicles, both selected next large follicles intersected on day 6 and day 10 (Fig. 1E). From day 9, follicle that its circumference increased transiently for one day became the next dominant while that continue increasing became the subordinate one.

Although the volume of the next dominant and subordinate significantly $(\mathrm{P}<0.0001)$ increased in parallel from day 3 but the rate of increase of next dominant follicle is higher than the next subordinate till day 12 but that of the subordinate one started to decrease starting from day 10 (Fig. 1F). On day 4, follicles having higher volume were selected but from day 10 , deviation accomplished by the increase of volume of the next dominant follicle and the concomitant decrease of the next subordinate one. 


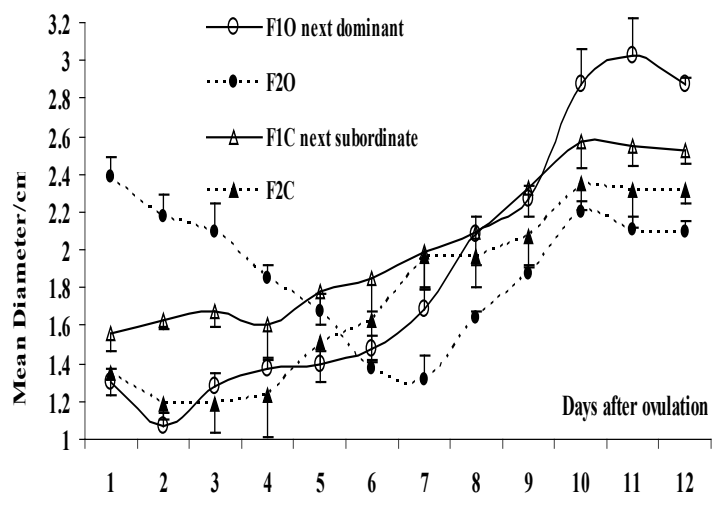

A

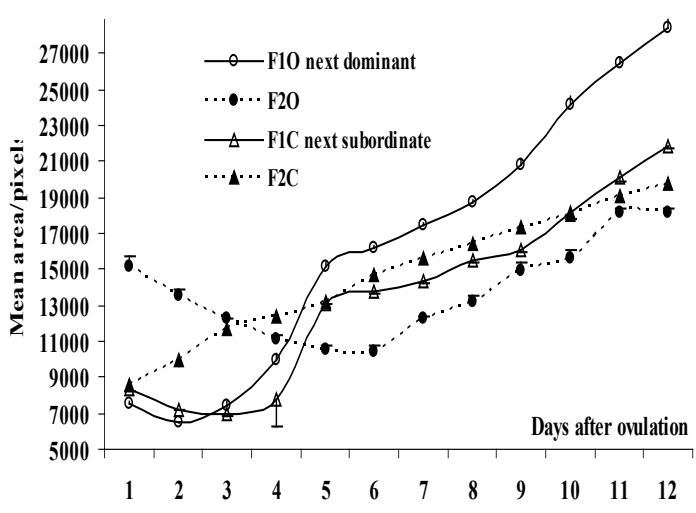

C

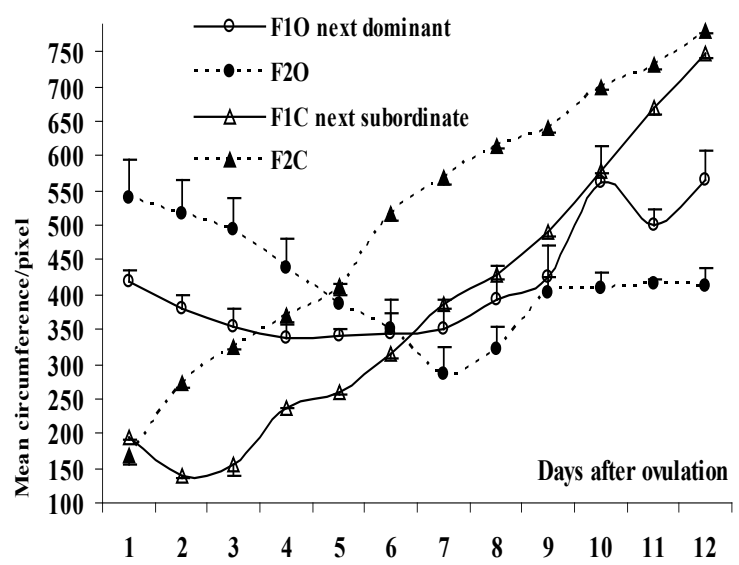

$\mathbf{E}$

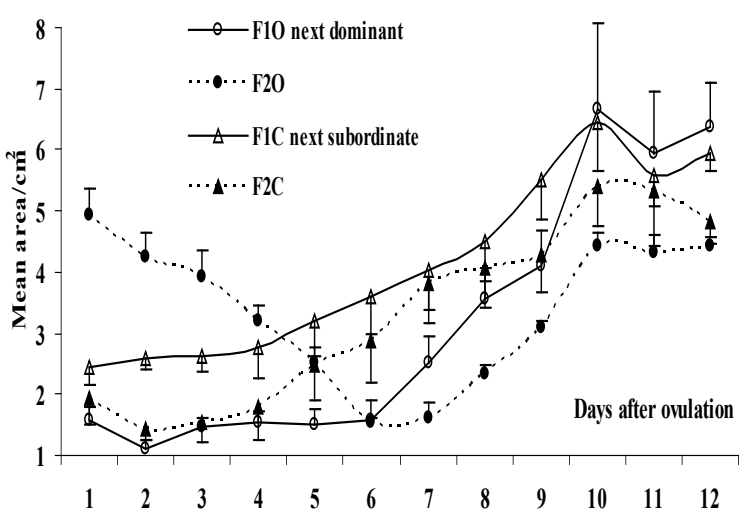

B

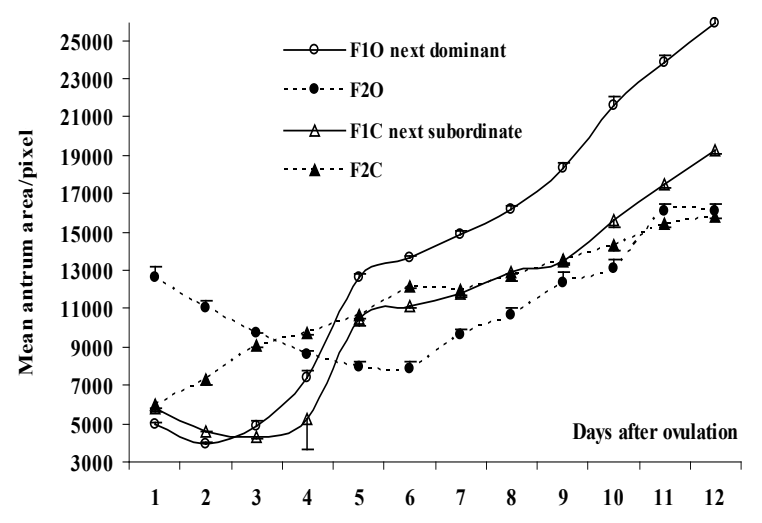

$\mathbf{F}$

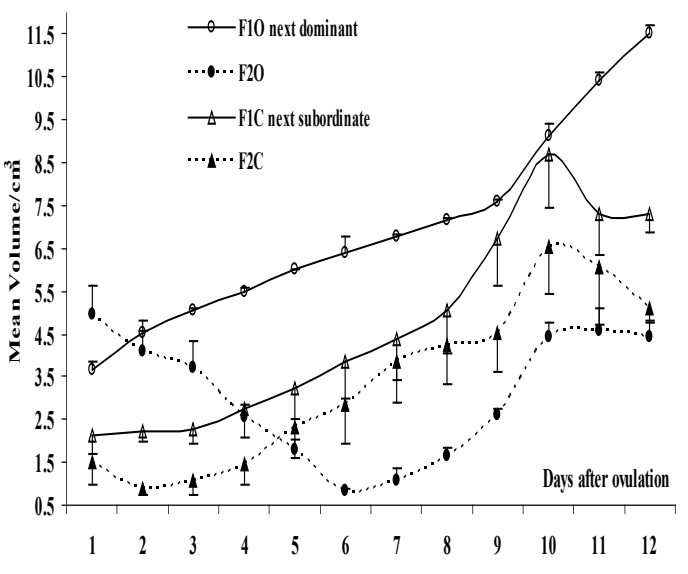

Figure 1. Mean Diameter/cm (A), area/ $\mathrm{cm}^{2}$ (B), area/pixel(C), antrum area/pixel (D), circumference (E) and volume $/ \mathrm{cm}^{3}(\mathrm{~F})$, of first large follicle on the CL ovary (F1O, next Dominant), second large follicle on the CL ovary (F2O), first large follicle on the non-CL ovary (F1C, next subordinate) and second large follicle on the non-CL ovary (F2C) from day 1 to day 12 after ovulation in mares with error bars. Ovary carrying CL (O), contralateral ovary $(\mathrm{C})$.

The color blood flow blue area of both selected follicles (Fig. 2A) started to increase significantly ( $\mathrm{P}<$ 0.0001 ) from day 4 and continued increasing till day 9 . Meanwhile blood flow of the next dominant continued increasing in a steady manner till reach high values on day 12 , that of the subordinate transiently decreased on day 9 then re-increased in a rate lower than that of the next dominant follicle.

On day 4 , the color blood flow red area of the two selected follicles decreased significantly $(\mathrm{P}<0.0001)$. The color blood flow red area of the next dominant follicle sharply increased on days 10 and 12 while that of the subordinate continued decreasing linearly $(\mathrm{P}<0.0001)$ till reach low values on day 12 (Fig. 2B).

On day 4, the next dominant $(\mathrm{P}<0.0001)$ and subordinate $(\mathrm{P}<0.0001)$ follicles had the same power blood flow area (Fig. 2C), but the next dominant follicle attained the lowest power blood flow area on day 5 while selection completed, after that its area of power Doppler continued increasing till day 9 but in a lower rate than the other follicles reaching a high value on day 10 then decreased again on day 11 reaching a low value 
compared to others.

By comparing the percent of the colored pixels to the total area of the follicle measured in pixels, the next dominant follicle had the highest percent of colored pixels on days 1 and 2 then sharply decrease till reach the lowest colored pixels on day 5 (Fig. 2D). When deviation of the next dominant follicle started on day 9 , a marked $(\mathrm{P}<0.0001)$ decrease of percent of the colored pixels was observed. By omitting area of antrum from each follicle area, the percent of the colored pixels without antrum of the selected follicle decreased sharply from day 4 to day 5 and became the lowest one. After completed selection on day 5, the next dominant follicle had highest percent of colored pixels that continued increasing $(\mathrm{P}<0.0001)$ till day 11 and became the only follicle having the highest percent of the colored pixels without counting its antrum from day 7 till day 11 indicating a higher blood flow (Fig. 2E).

A
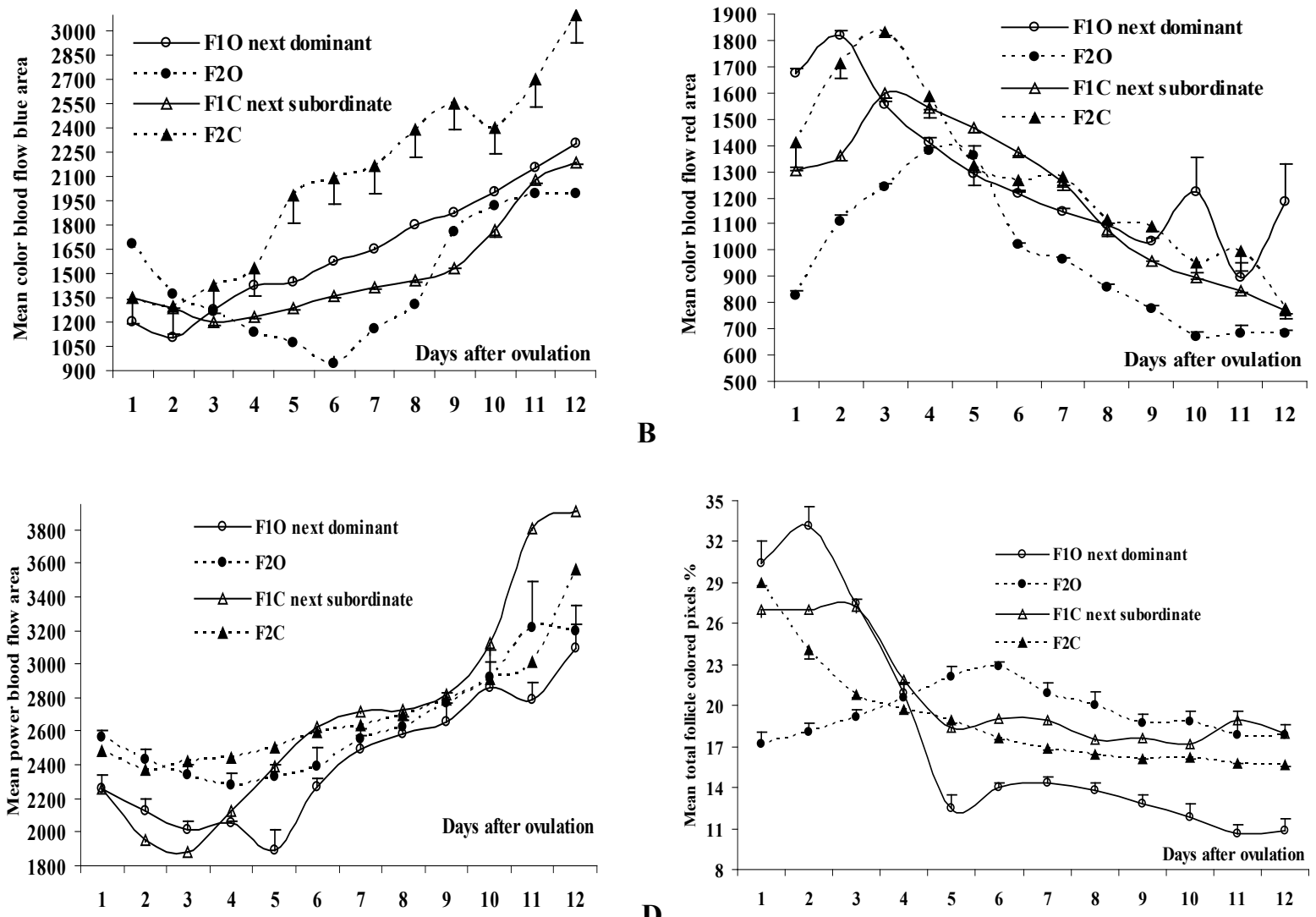

C
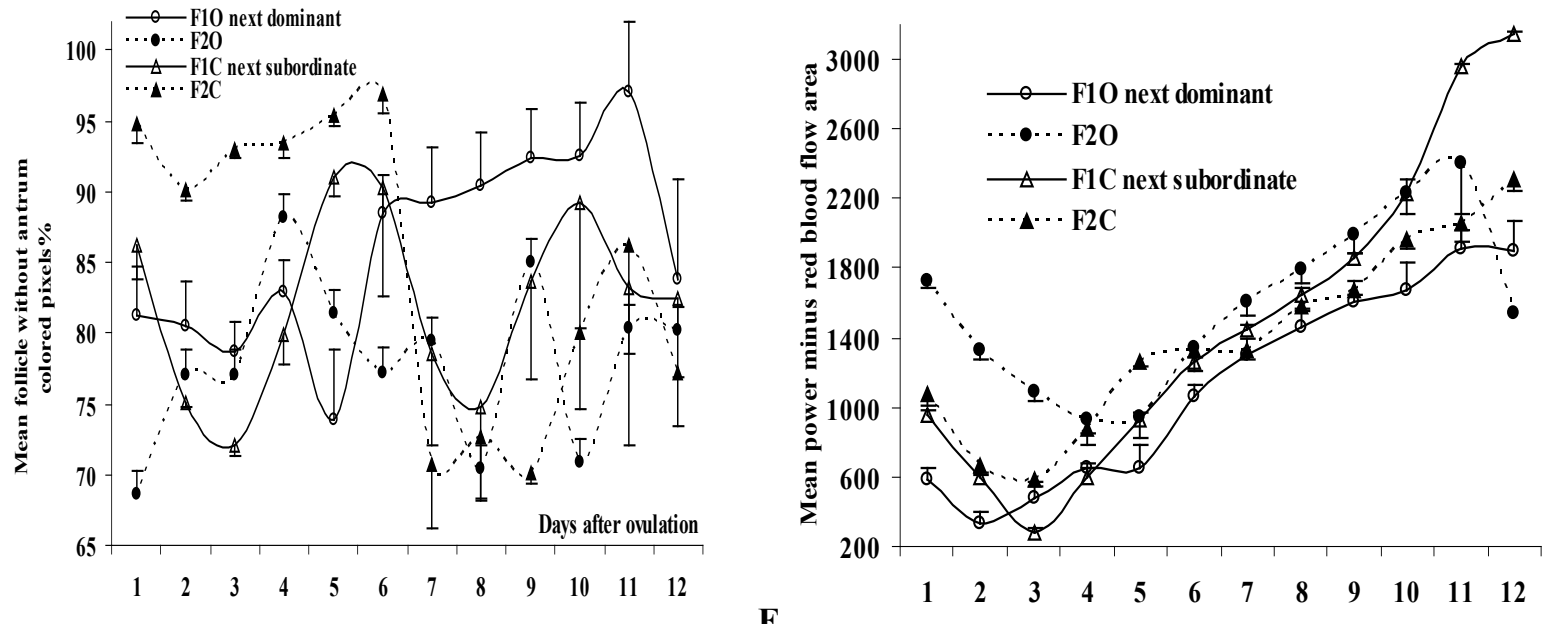

Figure 2. Mean color blood flow blue area (A), color blood flow red area (B), power blood flow area (C), percent of colored pixels of the follicle (D), percent of the colored pixels of the follicle without antrum(E) and difference between power and red color blood flow area (F) of first large follicle on the CL ovary (F1O, next Dominant), second large follicle on the CL ovary (F2O), first large follicle on the non-CL ovary (F1C, next subordinate) and second large follicle on the non-CL ovary ( F2C) from day 1 to day 12 after ovulation in mares with error bars. 
Days after ovulation significantly influenced (P $<0.0001)$ the difference between power and color blood flow red area of all follicles studied. It appeared from Fig. $2 \mathrm{~F}$ that the two follicles having similar and lowest power minus red color blood flow area on day 4 were selected. The follicle had the lowest power minus red color blood flow area from day 5 till day 9 became the next dominant. The slight decrease of power minus red color blood flow area of the next dominant on day 10 indicated that deviation is completed.

Circulating estradiol $(\mathrm{P}<0.0001)$ was referred to the growth of each follicle, it could be noticed that the two follicles growing during higher E2 on day 4 and also on day 9 became selected. Compared to other subordinates, systemic, estradiol (E2) was highest during the growth, selection and deviation of next dominant follicle indicating that E2 was necessary for selection and deviation of the next dominant follicle (Fig. 3A).

$\mathbf{A}$
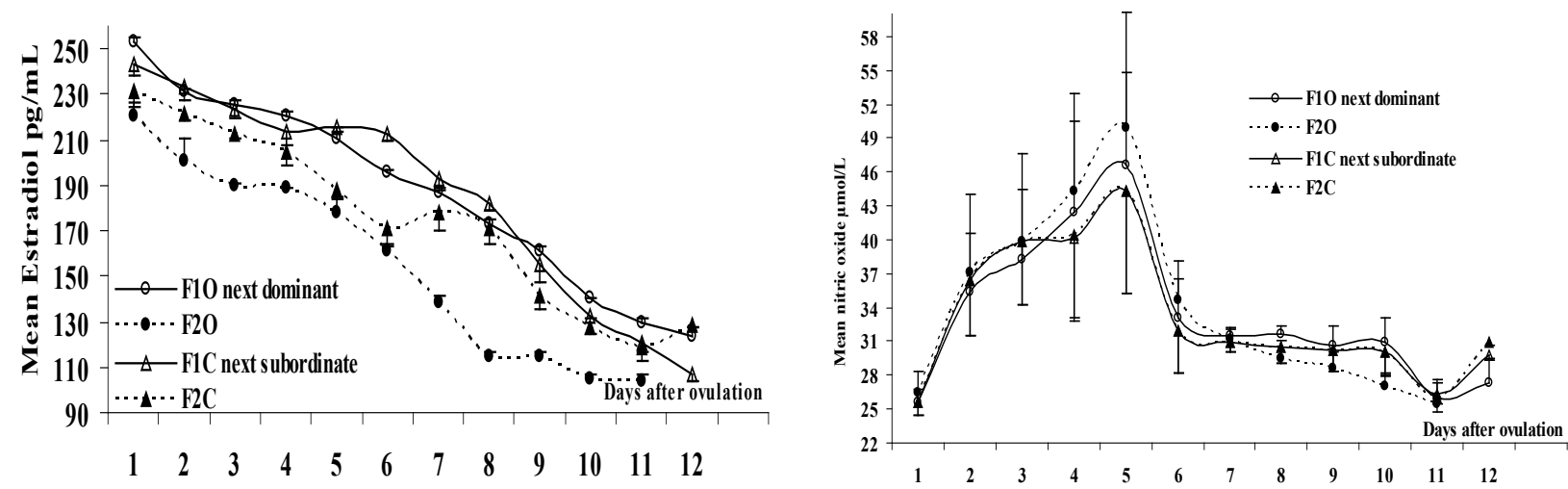

C
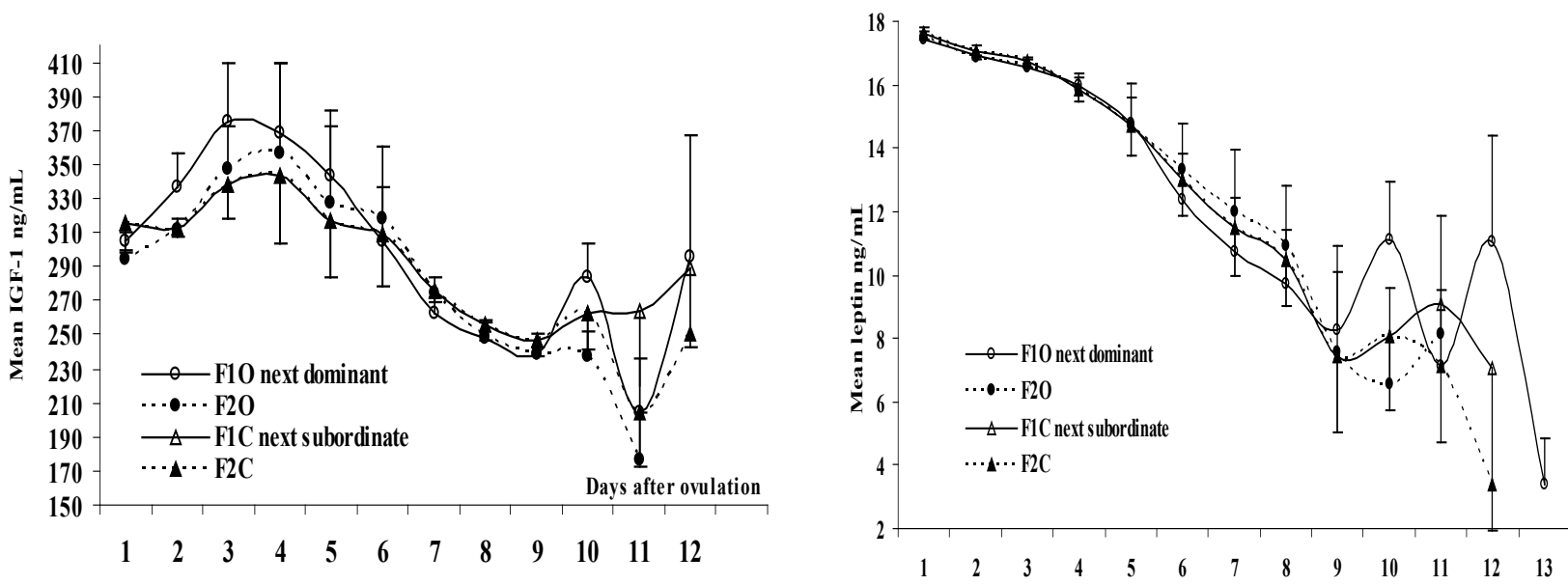

E
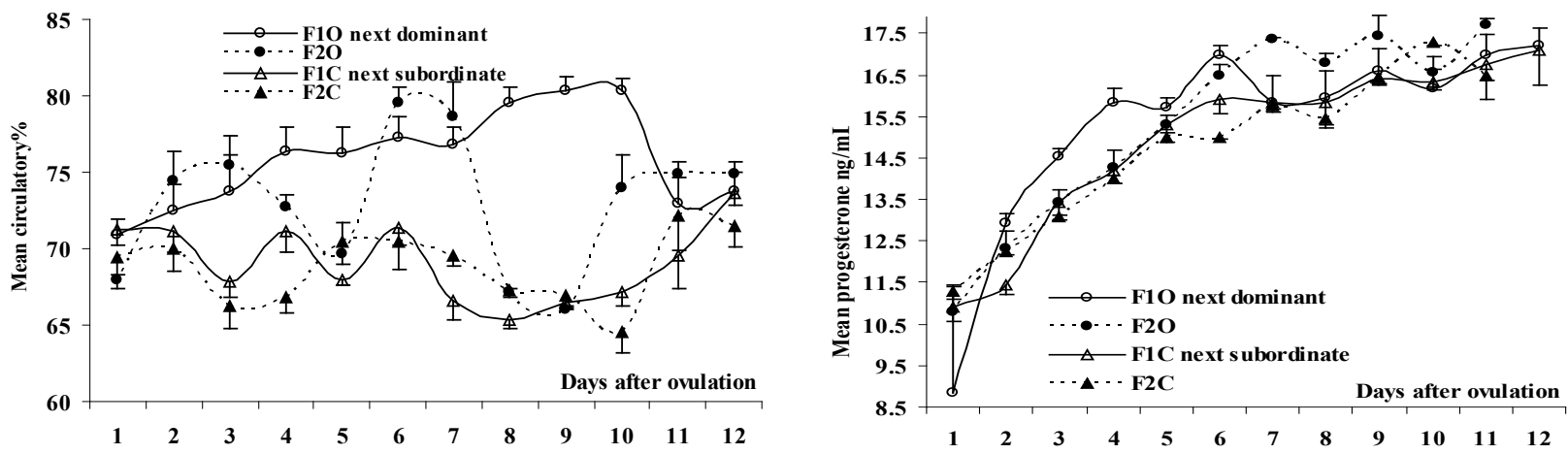

Figure 3. Mean estradiol (pg/mL, A), nitric oxide ( $\mu \mathrm{mol} / \mathrm{L}, \mathrm{B})$, Insulin like growth factor-I (IGF-1 ng/mL, C), Leptin $(\mathrm{ng} / \mathrm{mL}, \mathrm{D})$, circulatory $\%(\mathrm{E})$ and progesterone $(\mathrm{ng} / \mathrm{mL}, \mathrm{F})$ of first large follicle on the CL ovary $(\mathrm{F} 1 \mathrm{O}$, next Dominant), second large follicle on the CL ovary (F2O), first large follicle on the non-CL ovary (F1C, next subordinate) and second large follicle on the non-CL ovary ( F2C) from day 1 to day 12 after ovulation in mares with error bars. 
The similar increasing pattern of nitric oxide (NO) concentrations from day 2 till reaching a maximum on day 5 then sharply decreased on day 6 while follicle selection was completed indicated no role during follicle selection but the slight increasing concentrations of NO from day 9 till reach a comparable higher level between the next dominant and subordinates on day 10 and again on day 12 indicated a role in follicle deviation (Fig. 3B).

Circulating IGF-1 concentration increased from day 1 till Day 3 then started to decrease till day 5 but still higher during the selection of the next dominant follicle on days 4 and 5 indicating a role during selection of the next dominant and its increasing concentrations from the lowest concentration on day 9 to reach the highest peak on day 10 and the same increase was observed again on day 12 indicated another role during its deviation and maturation (Fig. $3 \mathrm{C})$.

After ovulation and during the growth of all studied follicles, circulating concentrations of leptin was similar but were decreasing from day 1 to day 5 indicating no role in selection, then it continue decreasing till day 9 but from day 9 circulating concentration of leptin increased and attained a maximum concentration that was also observed on day 12 indication a role in follicle deviation (Fig. 3D).

Follicle grew under high circulating progesterone on Day 4 were selected to be dominant and the transient decrease of progesterone $(\mathrm{P}<0.0001)$ on day 5 indicated completed selection (Fig. 3F), but the slight decrease of progesterone observed on day 8 just before deviation and on day 10 after deviation is completed indicated that low progesterone concentrations are necessary during selection and deviation of the next dominant follicle.

\section{Discussion}

Preparation for the next ovulation starts before the current ovulation and just 2 days after ovulation, selection of next dominant and subordinates starts since the largest follicles that continued growth and reached $>2.5 \mathrm{~cm}$ were monitored during the current study. Those two days following ovulation are considered post-estrus interval days, and then followed by diestrus (Marković, 2003). In Caspian mares, the mean time interval from ovulation until estrus no longer exists was $1.9 \pm 0.42$ days (Shirazi et al., 2004). In the current study, the diameter of the four tracked large follicles on day 1 after ovulation was $\geq 10 \mathrm{~mm}$ and was similar to the diameter of the six large follicles previously reported in pony mares (Ginther et al., 2007). Similarly, one out the four tracked large follicles studied continued growth and became the dominant follicle but another large follicle of nearly the same diameter reduced growth and became subordinate follicles (Gastal et al., 1997, 1999b; Ginther et al., 2004a, 2007, 2009). Mean diameter of the next dominant follicle at the beginning of deviation observed here was $22.7 \pm 0.7 \mathrm{~mm}$ and reached $28.7 \pm 1.9 \mathrm{~mm}$ one day later that is similar to several previously reported diameters of the future dominant follicle at the beginning of deviation $(23.7 \pm 0.6 \mathrm{~mm})$ in pony mares (Ginther, 1993, 2000; Donadeu and Ginther, 2004). Unlike Ginther (2000) and Ginther et al. (2007, 2009) but similar to Gastal et al., (1999b), mean diameter of the next subordinate follicle was similar to the next dominant 1 day before starting deviation and became slightly higher than that of the next dominant $(23.3 \pm$ $1.5 \mathrm{~mm}$ ) on the same day of starting deviation and the mean of $3 \mathrm{~mm}$ larger than the future subordinate follicle at the beginning of deviation was observed at the end of deviation but the growth rate of next subordinate was lower than the next dominant for 1 day after that its growth become retarded for the following 3 successive days allowing continued growth of the dominant follicle. This difference between the next dominant and subordinate follicles was not in favor of the next dominant follicle at day of starting deviation indicating that diameter was not necessary before starting deviation. In spite that deviation process started and ended nearly similar to that reviewed by Ginther et al. (2001) but was 5 days earlier than that reported for pony mares (Ginther et al., 2007), in spite that the diameter deviation was nearly similar and this may be attributed to the difference in season,breed, cycle length, age and size of the breed between the two studies. In agreement with our study follicles of nearly similar diameter grow at an approximately similar rate and each follicle has the capacity for future dominance (Gastal et al., 2004). Interestingly the current study recorded a similar increase of follicle diameter (Ginther, 1993, 2000; Donadeu and Ginther, 2004; Ginther et al., 2007, 2009). This study recorded also an increase of area and volume and antrum area of the next dominant follicle around deviation indicating that volume and antrum area is as important as diameter and the follicle that attained highest area due to the progressive increase of its antrum area was selected. Antrum area played a significant role from selection to deviation of the next dominant follicle. In agreement with our results, the rate at which the follicle antrum expansion and follicular fluid accumulation differs between dominant and subordinate follicles (Fortune et al., 1991; Beg et al., 2001: Beg and Ginther, 2006). In this study, by subtracting the antrum area from the follicle area around deviation we conclude that granulose layer showed no great change and the increase of the antrum area was referred to the osmotic gradient produced by granulose cells which draws in fluid derived from the thecal vasculature and to the relative permeability of the follicular wall allowing the aquaporins of the granulosa cells to be actively involved in the transport of water into the follicle (Rodgers and Irving-Rodgers, 2010), and greater thecal vascularity and blood supply of the dominant than subordinate follicles (Zeleznik et al., 1981; Redmer and Reynolds, 1996). The observed increase of the blood flow (color blood flow blue area) directed to the next dominant follicle parallel with the decrease of blood flow directed out the follicle (color blood flow red area) until completing deviation and the similar pattern of increase of percent of vascularization of the dominant follicle without antrum with the growth of the antrum confirmed the extravasations of blood 
leading to increased antrum area and in turn follicular fluid (Gastal et al., 1999a, 2004) and proved their role from selection to deviation. Similarly, the extravasations of blood plasma to the antrum increased not only diameter but also area and volume of the next dominant compared to the other subordinates (Ginther et al., 2003).

The increased percent of color blood flow area without antrum of the selected next dominant till completed its deviation compared to the other subordinates from day 6 (3 days before deviation) till day 12 agreed with the differential blood flow velocities between dominant and subordinates that was observed 2 days earlier than diameter deviation and the continued increase of velocity in dominant and the beginning of decrease in subordinate was referred to the reduced blood velocity or vascularity in the developing subordinate follicle due to the reduced proliferation of endothelial cells in follicle capillaries and reduced theca vascularity that were early events in follicle atresia in cattle (Jiang et al., 2003) and sheep (Jablonka-Sharif et al., 1994). In mares of this study, the increased percent of blood flow vascularization area without antrum started 3 to 4 days before deviation of both diameter and area. Moreover, the echotexture change distinguished the future dominant follicle from the future largest subordinate follicle observed one day earlier than the beginning of diameter deviation and was attributed to increased vascularisation (Uliani et al., 2011). As well as, vascular changes occurred 1 or 2 days before diameter deviation during follicle selection in mares (Acosta et al., 2004b), and this was referred to increased angiogenic factors in the largest follicle one day after the expected beginning of deviation (Ginther et al. 2004a). Similarly, deviation in flow area began 1 day before diameter deviation indicating that differential blood flow changes between future dominant and subordinate follicles precede diameter deviation during follicle selection through the continuation of the increasing blood supply to continue growing whereas the future subordinate follicles regress (Ginther et al., 2003). Also, vasculature proliferates and regresses throughout the lifespan of the follicle and is regulated independently within each follicle potentially making the functioning of its vasculature critically important in determining its fate (Fraser, 2006). The concurrent increase of estradiol, progesterone, leptin, IGF-1 and NO with increase of present of colored pixels without antrum from selection to deviation of the next dominant follicle was also recorded where follicular dominance is not only achieved by a follicle having a more extensive vasculature but also receiving greater hormonal support (Zeleznik et al., 1981). In this study, selection of the next dominant follicle did not relay on its diameter and the subordinated with larger diameter were not selected, this agreed with the explanation that selection of dominant follicle from those follicles that were estrogen active depended on vastly greater vascularisation due to angiogenic factors than their estrogen-inactive counterparts despite the estrogen-inactive follicle being larger in diameter (Grazul-Bilska et al., 2007). The increased area of power blood flow area, percent of the colored pixels and difference of area between power and red color blood flow area of the next subordinate follicle compared to the next dominant one from selection till after deviation is not supporting the previous observation that shortly after selection, there was a rapid degeneration of the thecal vasculature of the subordinate follicles initiating atresia (Jiang et al., 2003; Macchiarelli et al., 2006). The higher blood flow observed of next dominant follicle compared to subordinates was similar to the recorded increased blood flow area and also increased peak systolic velocity, end diastolic velocity and time average velocity during the growth of F1, F2 and F3 follicles from $6.5 \mathrm{~mm}$ to maximum $30.5 \mathrm{~mm}$ diameter that also confirmed that F1 had the highest blood flow indices (Acosta et al., 2004a). Moreover, ipsilateral to the corpus luteum, ovarian artery blood flow indicated an increased in all ovarian structures and confirmed the increased blood flow area measured from day 6 after ovulation (Bollwein et al., 2002). As well as, the dominant follicle had a greater thecal vascularity and blood supply than subordinate follicles (Redmer and Reynolds, 1996). However, Acosta et al. (2004b) demonstrated that the decreased vascularity in the future subordinate follicle began well before the growth rate of the follicle began to diminish.

Unlike the decreasing pattern of systemic estradiol from after ovulation till day 11 recorded in this study, E2 levels begin to decrease gradually 2 days after ovulation, reaching basal levels at day 5 post-ovulation (Ginther et al., 2004a, 2007, Satué et al., 2013). In contrast to the gradual decrease of estradiol from day 1 till day 11, Systemic estradiol concentrations increased 1 day before selection and deviation of the next dominant follicle in pony mares (Gastal et al., 1999b; Ginther et al., 2007). Moreover, intrafollicular estradiol concentrations increased with increasing diameter of the follicle from 15 to $25 \mathrm{~mm}$ and the high estradiol correlated to diameter of the larger follicles but showed no correlation to diameter of the smaller ones (Gastal et al., 1999b). Follicular-fluid estradiol increased at a greater rate differentially in the largest follicle versus the second-largest follicle before the beginning of deviation in mares (Gastal et al., 1999a; Donadeu and Ginther, 2002), near the beginning of deviation in diameter (Ginther et al., 2001, 2003), and also near the onset of deviation (Donadeu and Ginther, 2004). Contrary to our results, increased estradiol for 2 days after deviation was characterizing multiple ovulatory follicles development (Ginther et al., 2009). As well as, peripheral estradiol concentrations have been reported to increased near (Donadeu and Ginther, 2004), after (Ginther et al., 2005) the beginning of natural deviation, on the same day as the beginning of deviation (Ginther et al., 2007) or by 2 days after deviation (Ginther et al., 2009).

In the current study, NO concentrations increased during follicle selection compared to the slight increase during follicle deviated and this increase could be referred to the role of NO in regulating granulosa-luteal cell steroidogenesis (Van Voorhis et al., 1994). Moreover, NO concentrations increased in 
human follicular fluid, and positively correlated with follicular volume and oestradiol concentrations (Anteby et al., 1996). Systemic NO concentrations of the present study were nearly similar just before deviation and were high when deviation completed and 2 days after ending deviation. Contrary, NO concentrations were significantly lower in dominant compared to the largest subordinate the relationship between changes in follicular blood flow, NO concentrations and E2/P4 ratio was observed in follicular fluid following the beginning of diameter deviation (Pancarc et al., 2011).

During follicle selection, systemic IGF-1 of the current study attained a higher peak and another lower peak attained during dominant follicle deviation and the IGF levels during the selection and deviation of the next dominant follicle were higher compared to those during the other subordinate follicles development. The plateau of increased IGF-1 after ovulation from day 3 to day 5 during follicle selection and its increase again during and after deviation supports the role of IGF-1 in follicle selection and deviation. Within the equine ovary, the production of insulin like growth factors (IGF-I, IGF-II) and insulin like growth factor binding proteins (IGFBP2, IGFBP-5) by granulosa cells and estradiol confirmed their role in the regulation of steroidogenesis and the IGF system (Davidson et al., 2002). In agreement with our results, the lowest concentration of IGFBPs indicated high free IGFs and dominance (Mihm et al., 2000), and selection (Mazerbourg et al., 2003). In heifers, treating the subordinate follicle with IGF-1 had led to its deviation to dominance (Shahiduzzaman, 2010). As well as, in cattle and mares, free insulin-like growth factor 1 (IGF-1) was higher in the future dominant follicle than in the future largest subordinate follicle before deviation in diameter or selection is manifested between the two follicles (Ginther et al., $2004 \mathrm{~b}$ ). Similar to the increase of both circulating estradiol and IGF-1 during follicle selection and deviation observed in the current study, free IGF-1 concentration were higher only in the future dominant follicle approximately at the same time as the estradiol increase in mares (Ginther et al., 2004c). Furthermore, concentrations of free IGF-I, estradiol and progesterone were found to increase in the future dominant follicle before the beginning of deviation (Donadeu and Ginther, 2002). Also treatment of mares with IGF-1 resulted in deviation of the subordinate follicle to dominance after ablating the dominant one (Ginther et al., 2004a). In addition an increase in free IGF-I and oestradiol was greater in the future dominant follicle than in the other follicles before the beginning of deviation and the free IGF-I was considered the only factor needed for the initiation of deviation (Beg and Ginther, 2006). IGF-1 was also considered one of the regulators of angiogenesis in ovarian follicles and maintenance of capillary structures for final follicle maturation (Berisha et al., 2016).

The results of this study showed that the high concentrations of systemic leptin decreased after ovulation and continued decreasing till the process of follicle selection ended and the process of deviation started, indicating a role only during follicle deviation.
Similarly, the observed inverse relation between percentage of follicle wall with blood flow signal and intrafollicular leptin (Gastal et al., 2010). Leptin regulated angiogenesis (Bouloumie et al., 1998), and gonadotropin secretion via the regulation of $\mathrm{GnRH}$ function (Louis et al., 2011), and by activating nitric oxide synthase in the gonadotropes (Yu et al., 1997). In agreement with the current results, ovaries produced small amounts of leptin and the presence of its receptors in theca and granulosa cells and oocytes in the ovary confirm its role in follicle deviation (Fruhbeck, 2006). The decrease of circulating leptin concentrations after follicle selection and deviation indicated a role since higher leptin levels interfere with dominant follicle formation and suppress estradiol production in follicles under IGF-1 augmentation, which lead to insufficient LH surge and immature follicular development (Agarwal et al., 1999). Leptin accelerates follicular maturation by attenuating follicular atresia (Almog et al., 2001). Leptin can also suppress estrogen production stimulated by FSH and IGF-I in ovarian granulosa cells (Zachow and Magoffin, 1997) that explained the decreased leptin concentration just after ovulation, during follicle development, selection, till shortly before deviation and its increase during deviation of the dominant follicle indicated that leptin may have no role during follicle selection but play an important role during follicle deviation. Reduced blood flow through the ovarian stroma may lead to a follicular hypoxia that in turn induces the secretion of several angiogenic factors, such as leptin, in ovarian follicles. The increase of follicular fluid leptin stimulated angiogenesis under physiological and pathophysiological conditions (Barroso et al., 1999).

This study concluded that follicle diameter was not the only indicative marker of next dominant follicle selection and deviation but the process of follicle selection and deviation is a complicated process augments several factors some related to the follicles such as area, antrum area and volume while others related to vascularization within the follicle and blood flow in addition to the hormones controlling both follicle growth and angiogensis.

\section{Acknowledgments}

The authors wish to thank the staff officer doctors of El Basatten Horsley for granting horses to perform this study and National Research Center for availability of the Doppler Scanner and Faculty of Veterinary Medicine, Cairo University for the purchase of hormones.

\section{Conflict of interest}

The authors declare that they don't have any conflict of interest.

\section{References}

Abo El-Maaty AM, Gabr FI. 2010. Relation between leptin and estradiol level in Egyptian lactating Arab 
mares during foaling heat. Anim Reprod Sci, 117:95-98. Abo-El Maaty AM, El-Shahat KH. 2012. Hormonal and biochemical serum assay in relation to the estrous cycle and follicular growth in Arabian mare. Asian Pac J Reprod, 1:105-110.

Abo El-Maaty AM, Kotp MS, El-Tohamy, MM, El Natat WS, Mohamed AH. 2015. Role of leptin and insulin like growth factor-1 in breeding Egyptian horses along the year. J Med Biol Sci Res, 1:169-178.

Acosta TJ, Hayashi KG, Ohtani M, Miyamoto A. 2003. Local changes in blood flow within the preovulatory follicle wall and early corpus luteum in the cow. Reproduction, 125:759-767.

Acosta TJ, Beg MA, Ginther OJ. 2004a. Aberrant blood flow area and plasma gonadotropin concentrations during the development of dominantsized transitional anovulatory follicles in mares. Biol Reprod, 71:637-642.

Acosta TJ, Gastal EL, Gastal MO, Beg MA, Ginther OJ. 2004b. Differential blood flow changes between the future dominant and subordinate follicles precede diameter changes during follicle selection in mares. Biol Reprod, 71:502-507.

Acosta TJ, Hayashi KG, Matsui M, Miyamoto A. 2005. Changes in follicular vascularity during the first follicular wave in lactating cows. J Reprod Dev, 51:273280.

Agarwal SK, Vogel K, Weitsman SR, Magoffin DA. 1999. Leptin antagonizes the insulin-like growth factor-I augmentation of steroidogenesis in granulosa and theca cells of the human ovary. $J$ Clin Endocrinol Metab, 84:1072-1076.

Almog B, Gold R, Tajima K, Dantes A, Salim K, Rubinstein M, Barkan D, Homburg R, Lessing JB, Nevo N, Gertler A, Amsterdam A. 2001. Leptin attenuates follicular apoptosis and accelerates the onset of puberty in immature rats. Mol Cell Endocrinol, 183:179-191.

Anteby EY, Hurwitz A, Korach O, Revel A, Simon A, Finci-Yeheskel Z, Mayer M, Laufer N. 1996. Human follicular nitric oxide pathway: relationship to follicular size, oestradiol concentration and ovarian blood flow. Hum Reprod, 11:1947-1951

Bächler M, Menshykau D, De Geyter Ch, Iber D. 2014. Species-specific differences in follicular antral sizes result from diffusion-based limitations on the thickness of the granulosa cell layer. Mol Hum Reprod, 20:208-221.

Barroso G, Barrionuevo M, Rao P, Graham L, Danforth D, Huey S, Abuhamad A, Oehninger S. 1999. Vascular endothelial growth factor, nitric oxide, and leptin follicular fluid levels correlate negatively with embryo quality in IVF patients. Fertil Steril, 72:1024-1026.

Beg MA, Bergfelt DR, Kot K, Wiltbank MC, Ginther OJ. 2001. Follicular-fluid factors and granulosa-cell gene expression associated with follicle deviation in cattle. Biol Reprod, 64:432-441.

Beg MA, Ginther OJ. 2006. Follicle selection in cattle and horses: role of intrafollicular factors. Reproduction, 132:365-377.

Berisha B, Schams D, Rodler D, Pfaffl MW. 2016.
Angiogenesis in the ovary - the most important regulatory event for follicle and corpus luteum development and function in cow - an overview. Anat Histol Embryol, 45:124-130.

Bollwein H, Weber F, Kolberg B, Stolla R. 2002. Uterine and ovarian blood flow during the estrous cycle inmares. Theriogenology, 57:2129-2138.

Bouloumie A, Drexler HC, Lafontan M, Busse R. 1998. Leptin, the product of $\mathrm{Ob}$ gene, promotes angiogenesis. Circ Res, 83:1059-1066.

Davidson TR, Chamberlain CS, Bridges TS, Spicer LJ. 2002. Effect of follicle size on in vitro production of steroids and insulin-like growth factor (IGF)-I, IGF-II, and the IGF-binding proteins by equine ovarian granulosa cells. Biol Reprod, 66:1640-1648.

Dayi A, Bediz CS, Musal B, Yilmaz O, Comlekci A, Celiloglu M, Cimrin D. 2005. Comparison of leptin levels in serum and follicular fluid during the oestrous cycle in cows. Acta Vet Hung, 53:457-467.

Donadeu FX, Ginther OJ. 2002. Changes in concentrations of follicular fluid factors during follicle selection in mares. Biol Reprod, 66:1111-1118.

Donadeu FX, Ginther OJ. 2004. Interrelationships of estradiol, inhibin, and gonadotropins during follicle deviation in pony mares. Theriogenology, 61:13951405.

El-Sherry TM, Derar R, Bakry R. 2013. Changes in blood flow in ovine follicles and serum concentration of estradiol 17 beta (E2) and nitric oxide (NO) around the time of ovulation in Ossimi ewes. Anim Reprod Sci, 138:188-193.

Fahiminiya S, Gérard N. 2010. Follicular fluid in mammals. Gynecol Obstet Fertil, 38:402-404.

Feranil JB, Isobe N, Nakao T. 2004. Changes in the thecal vasculature during follicular atresia in the ovary of swamp buffalo. $J$ Reprod Dev, 50:315-321.

Fortune JE, Sirois J, Turzillo AM, Lavoir M. 1991. Follicle selection in domestic ruminants. J Reprod Fertil Suppl, 43:187-198.

Fortune JE, Rivera GM, Evans AC, Turzillo AM. 2001. Differentiation of dominant versus subordinate follicles in cattle. Biol Reprod, 65:648-654.

Fraser HM. 2006. Regulation of the ovarian follicular vasculature. Reprod Biol Endocrinol, 4:18. doi: 10.1186/1477-7827-4-18

Fruhbeck G. 2006. Intracellular signalling pathways activated by leptin. Biochem J, 393(pt. 1):7-20.

Gastal EL, Gastal MO, Bergfelt DR, Ginther OJ. 1997. Role of diameter differences among follicles in selection of a future dominant follicle in mares. Biol Reprod, 57:1320-1327.

Gastal EL, Donadeu FX, Gastal MO, Ginther OJ. 1999a, Echotextural changes in the follicular wall during follicle deviation in mares. Theriogenology, 52:803-814.

Gastal EL, Gastal MO, Wiltbank MC, Ginther OJ. 1999b. Follicle deviation and intrafollicular and systemic estradiol concentrations in mares. Biol Reprod, 61:31-39.

Gastal EL, Gastal MO, Beg MA, Ginther OJ. 2004. Interrelationships among follicles during the commongrowth phase of a follicular wave and capacity of 
individual follicles for dominance in mares. Reproduction, 128:417-422.

Gastal EL, Gastal MO, Ginther OJ. 2006. Relationships of changes in B-mode echotexture and color-Doppler signals in the wall of the preovulatory follicle to changes in systemic oestradiol concentrations and the effects of human chorionic gonadotrophin in mares. Reproduction, 131:699-709.

Gastal MO, Gastal EL, Beg MA, Ginther OJ. 2010. Short-term feed restriction decreases the systemic and intrafollicular concentrations of leptin and increases the vascularity of the preovulatory follicle in mares. Theriogenology, 73:1202-1209.

Ginther OJ. 1993. Major and minor follicular waves during the equine estrous cycle. J Equine Vet Sci, 13:1825.

Ginther OJ, Wiltbank MC, Fricke PM, Gibbons JR, Kot K. 1996. Selection of the dominant follicle in cattle. Biol Reprod, 55:1187-1194.

Ginther OJ. 2000. Selection of the dominant follicle in cattle and horses. Anim Reprod Sci, 60/61:61-79.

Ginther OJ, Beg MA, Bergfelt DR, Donadeu FX, Kot K. 2001. Follicle selection in monovular species. Biol Reprod, 65:638-647

Ginther OJ, Beg MA, Donadeu FX, Bergfelt DR. 2003. Mechanism of follicle deviation in monovular farm species. Anim Reprod Sci, 78:239-257.

Ginther OJ, Beg MA, Gastal MO, Gastal EL. 2004a. Follicle dynamics and selection in mares. Anim Reprod, 1:45-63.

Ginther OJ, Bergfelt DR, Beg MA, Meira C, Kot K. 2004b. In vivo effects of an intrafollicular injection of insulin-like growth factor 1 on the mechanism of follicle deviation in heifers and mares. Biol Reprod, 70:99-105.

Ginther OJ, Gastal EL, Gastal MO, Beg MA. 2004c. Critical role of insulin-like growth factor system in follicle selection and dominance in mares. Biol Reprod, 70:1374-1379.

Ginther OJ, Gastal EL, Gastal MO, Checura CM, Beg MA. 2004d. Dose-response study of intrafollicular injection of insulin-like growth factor-1 on follicularfluid factors and follicle dominance in mares. Biol Reprod, 70:1063-1069.

Ginther OJ, Beg MA, Gastal EL, Gastal MO, Baerwald AR, Pierson RA. 2005. Systemic concentrations of hormones during development of follicular waves in mares and women: a comparative study. Reproduction, 130:379-388.

Ginther OJ, Utt MD, Beg MA. 2007. Follicle deviation and diurnal variation in circulating hormone concentrations in mares. Anim Reprod Sci, 100:197-203. Ginther OJ, Jacob JC, Gastal MO, Gastal EL, Beg MA. 2009. Development of one vs multiple ovulatory follicles and associated systemic hormone concentrations in mares. Reprod Domest Anim, 44:441-449.

Ginther OJ. 2012. The mare: a 1000-pound guinea pig for study of the ovulatory follicular wave in women. Theriogenology, 77:818-828.

Grazul-Bilska AT, Navanukraw C, Johnson ML, Vonnahme KA, Ford SP, Reynolds LP, Redmer DA. 2007. Vascularity and expression of angiogenic factors in bovine dominant follicles of the first follicular wave.
J Anim Sci, 85:1914-1922.

Jablonka-Sharif A, Fricke PM, Grazul-Bilska AT, Reynolds LP, Redmer DA. 1994. Size, number, cellular proliferation and atresia of gonadotropininduced follicles in ewes. Biol Reprod, 51:531-540.

Jiang JY, Macchiarelli G, Tsang BK, Sato E. 2003. Capillary angiogenesisand degeneration in bovine ovarian antral follicles. Reproduction, 125:211-223.

Kerban A, Doré M, Sirois J. 1999. Characterization of cellular and vascular changes in equine follicles during hCG-induced ovulation. J Reprod Fertil, 117:115-123.

Kitawaki J, Kusuki I, Koshiba H, Tsukamoto K, Honj OH. 1999. Leptin directly stimulates aromatase activity in human luteinized granulosa cells. Mol Hum Reprod, 5:708-713.

Louis GW, Greenwald-Yarnell M, Phillips R, Coolen LM, Lehman MN, Myers MG Jr. 2011. Molecular mapping of the neural pathways linking leptin to the neuroendocrine reproductive axis. Endocrinology, 152:2302-2310.

Macchiarelli G, Jiang JY, Nottola SA, Sato E. 2006. Morphological patterns of angiogenesis in ovarian follicle capillary networks. A scanning electron microscopy study of corrosion cast. Microsc Res Tech, 69:459-468.

Marković, D. Pavlović M., Pavlović V. 2003. Seasonality, folliculogenesis and luteogenesis in mare ovaries. Facta Univ Ser Med Biol, 10:120-126.

Mazerbourg S, Bondy CA, Zhou J, Monget P. 2003.

The insulin - like growth factor system: a key

determinant role in the growth and selection of ovarian follicles? a comparative species study. Reprod Domest Anim, 38:247-258.

Mihm M, Austin EJ, Good TEM, Ireland JLH, Knight PG, Roche JF, Ireland JJ. 2000. Identification of potential intrafollicular factors involved in selection of dominant follicles in heifers. Biol Reprod, 63:811819.

Miura R, Haneda S, Lee HH, Miyamoto A, Shimizu T, Miyahara K, Miyake Y, Matsui M. 2014. Evidence that the dominant follicle of the first wave is more active than that of the second wave in terms of its growth rate, blood flow supply and steroidogenic capacity in cows. Anim Reprod Sci, 145:114-122.

Okuda Y, Okamura H, Kanzaki H, Takenaka A, Morimoto K, Nishimura T. 1982. [An ultrastructural study of capillary permeability of rabbit ovarian follicles during ovulation using carbon tracer (author's transl)]. Nihon Sanka Fujinka Gakkai Zasshi, 34:181186.

Pancarc SM, Güngör O, Atakişi O, Ciğremiş Y, Arı UÇ, Bollwein H. 2011. Changes in follicular blood flow and nitric oxide levels in follicular fluid during follicular deviation in cows. Anim Reprod Sci, 123:149156.

Redmer DA, Reynolds LP. 1996. Angiogenesis in the ovary. Rev Reprod, 1:182-192.

Rodgers RJ, Irving-Rodgers HF. 2010. Formation of the ovarian follicular antrum and follicular fluid. Biol Reprod, 82:1021-1029.

Roman EA, Ricci AG, Faletti AG. 2005. Leptin enhances ovulation and attenuates the effects produced 
by food restriction. Mol Cell Endocrinol, 242:33-41. Rosselli M, Imthurn B, Macas E, Keller PJ, Dubey RK. 1994. Circulating nitrite/nitrate increase with follicular development: indirect evidence for estradiol mediated release. Biochem Biophys Res Commun, 202:1543-1552.

Rosselli M, Keller PJ, Dubey RK. 1998. Role of nitric oxide in the biology, physiology and pathophysiology of reproduction. Hum Reprod Update, 4:3-24.

Satué K, Montesinos P, Gardon JC. 2013. Influence of oestrogen and progesterone on circulating neutrophils and monocyte during ovulatory and luteal phase in healthy Spanish Purebred mares. In: Proceedings of XIX Congress of Societa Italiana Veterinari per Equini. Cremona: SIVE. pp. 383-384.

Shahiduzzaman AK, Beg MA, Palhao MP, Siddiqui MA, Shamsuddin M, Ginther OJ. 2010. Stimulation of the largest subordinate follicle by intrafollicular treatment with insulin-like growth factor 1 is associated with inhibition of the dominant follicle in heifers. Theriogenology, 74:194-201.

Shirazi A, Gharagozloo F, Ghasemzadeh-Nava $H$. 2004. Ultrasonic characteristics of preovulatory follicle and ovulation in Caspian mares. Anim Reprod Sci, 80:261-266.

Sierra-Honigmann MR, Nath AK, Murakami C, Garcia-Cadena G, Papapetropoulos A, Sessa WC, Madge LA, Schechner JS, Schwabb MB, Polverini PJ, Flores-Riveros JR. 1998. Biological action of leptin as an angiogenic factor. Science, ;281:1683-1686 Spicer LJ, Tucker KE, Henderson KA, Duby RT. 1991. Concentrations of insulin-like growth factor-I in follicular fluid and blood plasma of mares during early and late oestrus. Anim Reprod Sci, 25:57-65.

Uliani RC, Silva LA, Alvarenga MA. 2011. Mare's Folliculogenesis: assessment of ovarian and perifollicular vascular perfusion by Doppler ultrasound. Acta Sci Vet, 39(suppl. 1):s113-s116.
Van Voorhis BJ, Dunn MS, Snyder GA Weiner CP. 1994. Nitric oxide: an autocrine regulator of human granulose-luteal cell steroidogenesis. Endocrinology, 135:1799-1806.

Wood KC, Cortese-Krott MM, Kovacic JC, Noguchi A, Liu VB, Wang X, Raghavachari N, Boehm M, Kato GJ, Kelm M, Gladwin MT. 2013. Circulating blood endothelial nitric oxide synthase contributes to the regulation of systemic blood pressure and nitrite homeostasis. Arterioscler Thromb Vasc Biol, 33:18611871.

Wulff C, Wilson H, Wiegand SJ, Rudge JS, Fraser HM. 2002. Prevention of thecal angiogenesis, antral follicular growth, and ovulation in the primate by treatment with vascular endothelial growth factor Trap R1R2. Endocrinology, 143:2797-2807

Yu WH, Walczewska A, Karanth S, McCann SM. 1997. Nitric oxide mediates leptin-induced luteinizing hormone-releasing hormone (LHRH) and LHRH and leptin-induced $\mathrm{LH}$ release from the pituitary gland. Endocrinology,138:5055-5058

Yuan W, Bao B, Garverick HA, Youngquist RS, Lucy MC. 1998. Follicular dominance in cattle is associated with divergent patterns of ovarian gene expression for insulin-like growth factor (IGF)-I, IGFII, and IGF binding protein-2 in dominant and subordinate follicles. Domest Anim Endocrinol, 15:5563.

Zachow RJ, Magoffin DA. 1997. Direct intraovarian effects of leptin: impairment of the synergistic action of insulin-like growth factor-I on follicle-stimulating hormone-dependent estradiol- 17 beta production by rat ovarian granulosa cells. Endocrinology, 138:847-850.

Zeleznik AJ, Schuler HM, Reichert LE. 1981. Gonadotropin-binding sites in the rhesus monkey ovary: role of the vasculature in the selective distribution of human chorionic gonadotropin to the preovulatory follicle. Endocrinology, 109:356-362. 